\title{
PSYCHOSOCIAL IMPACT OF CORONAVIRUS LOCKDOWN ON NIGERIANS
}

Godfrey Ejiroghene Akpojotor ${ }^{1}$, Otega Okinono ${ }^{2}$, E O Ndakara ${ }^{3}$, Calistar Kidochukwu $\mathrm{Obi}^{4}$, Patrick Ifeanyi Okonta ${ }^{5}$, Emmanuel Morka ${ }^{6}$, Abel Maviano Jonathan ${ }^{7}$, Emmanuel Ozioma Michael ${ }^{8}$, Wisdom Oghenevwogaga Egboduku ${ }^{8}$, Newton Ighomaro Okposo ${ }^{7}$, Benard Chinedu Okolugbo ${ }^{9}$, Theodora Ogharanduku ${ }^{9,10}$, Nathanial Okpara ${ }^{11}$, Ewomazino Odibo $^{9}$, Marcus Ifeanyi Ossiaugbo ${ }^{7}$, Benjamin Ubreye Owhe-Ureghe ${ }^{6,12}$, Mary Oghenerioborue Agbogidi ${ }^{8,13}$, Godwin Avwioro ${ }^{14}$, Nyerovwo John Tonukari ${ }^{15}$, Godfrey Ejiroghene Akpojotor ${ }^{11,16}$, Patrick Goddey Nmorsi ${ }^{9,17}$, and Andy Ogochukwu Egwunyenga ${ }^{9,18}$

${ }^{1}$ Affiliation not available

${ }^{2}$ Department of Economics, Delta State University

${ }^{3}$ Department of Sociology and Psychology, Delta State University

${ }^{4}$ Department of Geography and regional Planning, Delta State University

${ }^{5}$ Department of Obstetrics and Gynaecology, Faculty of Clinical Medicine, College of Health Sciences

${ }^{6}$ Department of Microbiology, Delta State University

${ }^{7}$ Department of Mathematics, Delta State University

${ }^{8}$ Department of Botany, Delta State University

${ }^{9}$ Department of Animal and Environmental Biology, Delta State University

${ }^{10}$ Department of Infectious Disease Epidemiology, School of Hygiene and Tropical Medicine

${ }^{11}$ Department of Physics, Delta State University

${ }^{12}$ Centre for Biotechnology Research, Delta State University

${ }^{13}$ Centre for Plants Conservation and Utilization, Delta State University

${ }^{14}$ Department of Science Laboratory Technology, Delta State University

${ }^{15}$ Department of Biochemistry, Delta State University

${ }^{16}$ Centre for Research and International Programmes, Delta State University

${ }^{17}$ Advanced Research Centre, Delta State University

${ }^{18}$ Vice Chancellor's Office, Delta State University

November 11, 2020

\section{Hosted file}

The Psychosocial manuscript Version 1.pdf available at https://authorea.com/users/369252/ articles/488178-psychosocial-impact-of-coronavirus-lockdown-on-nigerians 